\title{
Detection of initial effects of pollution on marine benthos: an example from the Ekofisk and Eldfisk oilfields, North Sea
}

\author{
John S. Gray ${ }^{1}$, K. R. Clarke ${ }^{2}$, R. M. Warwick ${ }^{2}$, G. Hobbs ${ }^{3}$ \\ ${ }^{1}$ Department of Marine Biology and Chemistry, University of Oslo, N-0316 Blindern, Oslo 3, Norway \\ ${ }^{2}$ Plymouth Marine Laboratory, West Hoe, Plymouth PL1 3DH, England \\ ${ }^{3}$ Field Studies Council Research Centre, Oil Pollution Research Unit, Fort Popton, Angle, Pembroke, Dyfedd SA71 5AD, Wales
}

\begin{abstract}
Reductions in number of species and diversity and increased dominance of opportunistic species occurred late in the sequence of response to oil as a stress factor (within 500 to $1000 \mathrm{~m}$ of discharge sources). However, multivariate analyses, (classification analysis using the Bray-Curtis dissimilarity index) and ordination (multi-dimensional scaling) clearly distinguished site groupings related to oil activities at distances of up to 2 to $3 \mathrm{~km}$ from the Ekofisk pollution source and up to $1.5 \mathrm{~km}$ from the Eldfisk source. The first recorded changes in benthic communities in response to oil were increased abundance patterns of some species and changes in the presence and absence patterns of rare species, with species being mostly present in one site group and mostly absent in another site group. Only under severe pollution did the opportunistic species, which have often been suggested as universal indicators of pollution, dominate. The major site groupings could still be distinguished after aggregation to higher taxa (families and even phyla) when using multivariate analyses. If this finding proves to be a general one then great savings in time and effort, with little or no loss of precision, will be possible in environmental monitoring.
\end{abstract}

\section{INTRODUCTION}

Benthic communities are widely used in the monitoring of effects of marine pollution as the organisms are mostly sessile and integrate effects of pollutants over time. Most benthic communities comprise a large number of species and because of the varying sensitivities of species it should be possible to identify subtle effects of pollutants reflected in changes in community structure. Until fairly recently, the accepted methods for identifying pollution-induced changes have been relatively crude, using changes in total number of species, diversity indices and frequency of occurrence of opportunistic species, but in a recent review of such stress indices Gray (1989) suggests that they indicate end-points rather than first effects of pollution-induced change.

Newer methods have been suggested such as the distribution of individuals among species (Gray \& Pearson 1982), and species abundance: biomass comparisons (ABC) (Warwick 1986), but only a few comparative studies have been done (Gray et al. 1988, Heip et al. 1988, Warwick 1988, Warwick et al. 1988), Here we explore use of a variety of techniques and compare these with multivariate analyses. Although multivariate analyses have been used in benthic community analyses for some time (Field 1970, Stephenson et al. 1970, Boesch 1971, Hughes \& Thomas $1971 \mathrm{a}, \mathrm{b}$, Field et al. 1982) our primary aim is to compare the effectiveness of these against other techniques (see also Gray et al. 1988).

Oil companies are usually required to monitor the effects of their activities on marine life, but there are few published accounts of effects on the benthos of the North Sea. Davies et al. (1984) gave a brief review of effects over fields within the British sector. Hartley (1984) reviewed effects of oil on the benthos of the North Sea and this was updated by Kingston (1987). The general concensus is that effects of oil activities are found out to $1 \mathrm{~km}$ from the oil boring platform or production rig with rather severe effects being found within a $500 \mathrm{~m}$ radius. Within $500 \mathrm{~m}$ the macrofauna is dominated by opportunist species, and has low diversity and low biomass. Out to $1 \mathrm{~km}$ diversity is lower than in more remote areas

In the Norwegian sector, oil companies have, by law, 
to submit results of environmental surveys around their installations to the State Pollution Board (Statens Forurensnings Tilsyn) every second year. In 1987 the Pollution Board initiated a process of independent reviews and found that the quality of the reports varied enormously and thereafter quality control measures were introduced (Reiersen et al. 1989). Recent surveys are, therefore, in a more standardised format. A survey of the Ekofisk field carried out in 1987 (Hobbs 1987) was submitted to the Pollution Board and provides the basis of this paper. The Ekofisk field includes Ekofisk itself and Eldfisk, $10 \mathrm{~km}$ distant in a southerly direction. All the analyses were done by us independently of those described in the original report and are based on the species-site matrix in the submitted report (Hobbs 1987).

\section{HISTORY OF THE FIELDS}

Exploration of the Ekofisk field began in the late 1960 's and the first environmental investigation around the main platform complex was carried out in 1973. Further stations were added to the sampling grid in the third and fifth surveys (1977 and 1984 respectively) in order to provide more information on the effects of activity at the $2 / 4 \mathrm{~B}$ and $\mathrm{K}$ platforms.

Environmental investigations in the adjacent Eldfisk field began in 1984 in conjunction with the fifth survey of the Ekofisk field. This paper is based on the results of the sixth environmental survey of the Ekofisk field and the second survey at Eldfisk. The Eldfisk field is much younger than Ekofisk, having been in production since 1979, and effects of oilfield industrial activity on the benthos can be expected to be much less severe. Discharge of oil from the Ekofisk platform alone in the years 1983 to 1986 was 65, 53, 11 and 0 tons respectively, whereas the discharge of oil-based drilling muds was 697 tons in 1984, 206 tons in 1985 and 0 tons in 1986 (Norwegian State Pollution Board 1987 pers. comm.). No comparable data are available from the Eldfisk field.

Due to the longer history of oil activities, effects around the Ekofisk field might be expected to be more far-reaching than around the Eldfisk field and represent cumulative effects of discharges in past years rather than representing effects of recent discharges. As Ekofisk is the oldest field in the Norwegian sector, the findings are of relevance to more recent field developments.

\section{MATERIALS AND METHODS}

Sampling sites were arranged as radij and are approximately logarithmically spaced with 38 sites located at the Ekofisk field and 20 at Eldfisk, with a reference station located $30 \mathrm{~km}$ east of Ekofisk (Fig. 1). At each site 3 grab samples were taken with a Day grab $\left(0.1 \mathrm{~m}^{2}\right)$, sampling to a minimum depth of $10 \mathrm{~cm}$, and the samples were sieved on a $1 \mathrm{~mm}$ sieve. Samples were preserved in formalin and sorted after staining with eosin. Individuals were identified to species where possible, but in some cases only to higher taxa.

An additional grab sample was taken at each site for analysis of sediment particle size, organic matter and major trace metals. Subsamples were taken from the uppermost $5 \mathrm{~cm}$ of the grab for analysis of hydrocarbons. (Details of methods used can be found in Hobbs 1987.)

A matrix comprising the number of individuals of each species at each site was composed. A large number of juvenile echinoderms of indeterminate species were found. These were excluded from the statistical analyses. We do not regard the juvenile echinoderms (or any other juveniles for that matter) as an integral part of the benthic community because they had not had sufficient time to equilibrate to local environmental conditions. Furthermore, analyses done with and without the juvenile echinoderms showed that their presence confounded the univariate analyses but made little difference to the multivariate analyses. Analyses were done on the total numbers pooled over the grab replicates from each site.

The traditional methods of analysing effects of pollutants involve plotting the number of species and abundance of individuals across gradients of the pollutant and this was done here. Further comparisons were made by plotting species-abundance patterns (Gray \& Pearson 1982). In addition a variety of diversity indices was calculated, but here only the Shannon-Wiener index will be discussed.

Two basic multivariate techniques were used: a hierarchical classification technique based on the BrayCurtis similarity coefficient calculated on square root transformed abundances, employing group average sorting, and an ordination technique (multi-dimensional scaling) based on the ranked Bray-Curtis similarity matrix (see Field et al. 1982, Gray et al. 1988 for further details of application of these techniques). Following a cluster analysis, the species having the greatest contribution to the division of sites into clusters were determined using the similarity percentages (SIMPER) program, described in Warwick et al. (1990). For a comparison between clusters, the average dissimilarity $(\bar{\delta})$ over all pairs of sites in different clusters is computed. From this is extracted the contribution $\left(\delta_{1}\right)$ of the $i$ th species, defined simply by the $i$ th terms in the summation over $i$ that constitutes the Bray-Curtis dissimilarity coefficient. This can be expressed as an absolute dissimilarity value (as in Table 2 ) or in terms of the percentage it contributes to the total (average) dissimi- 


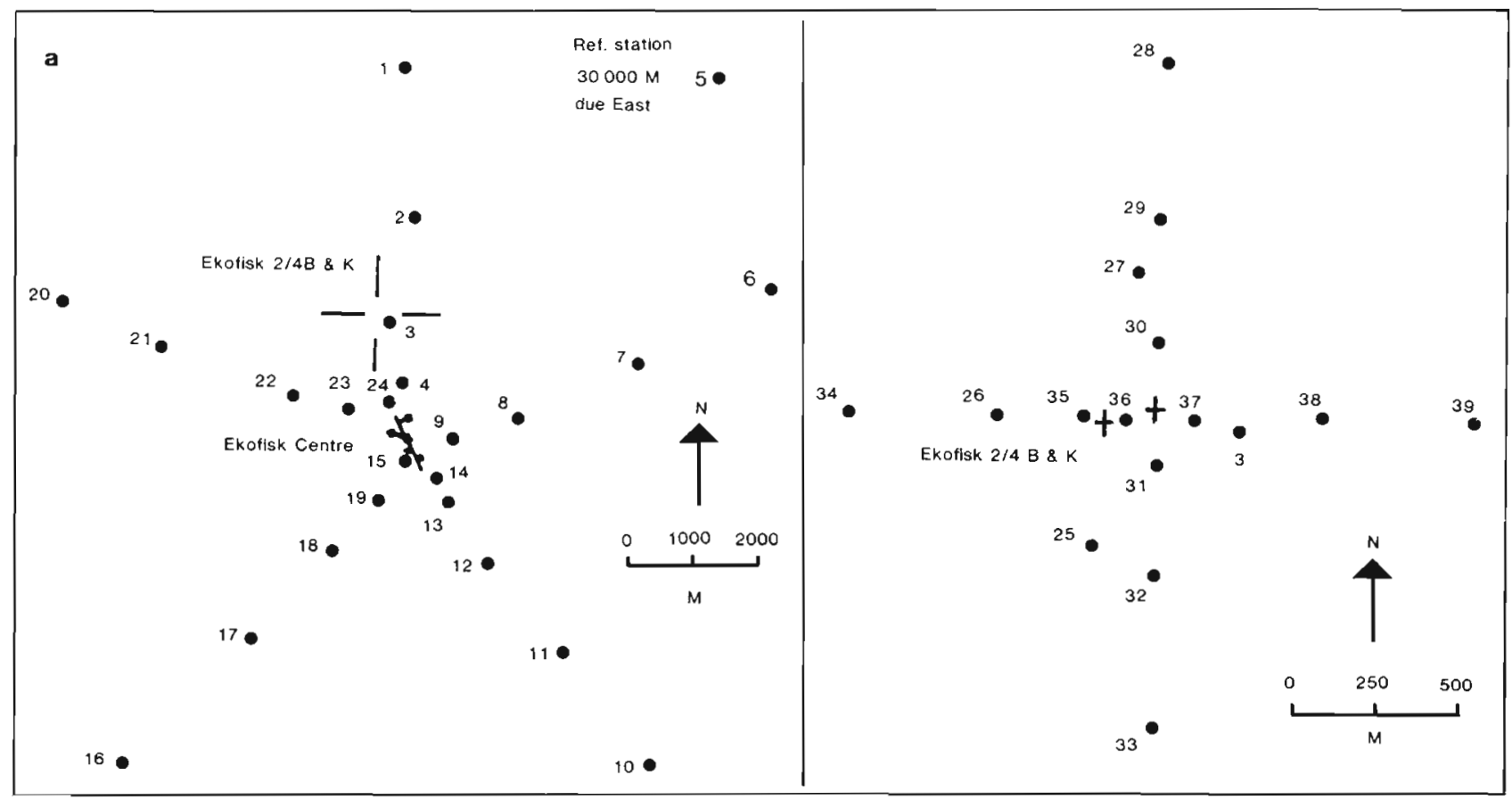

Fig. 1. Location of sampling sites at (a) Ekofisk and (b) Eldfisk fields, North Sea, July 1987. At Ekofisk the central complex and the newer $2 / 4 \mathrm{~B}$ \& $\mathrm{K}$ complexes are shown

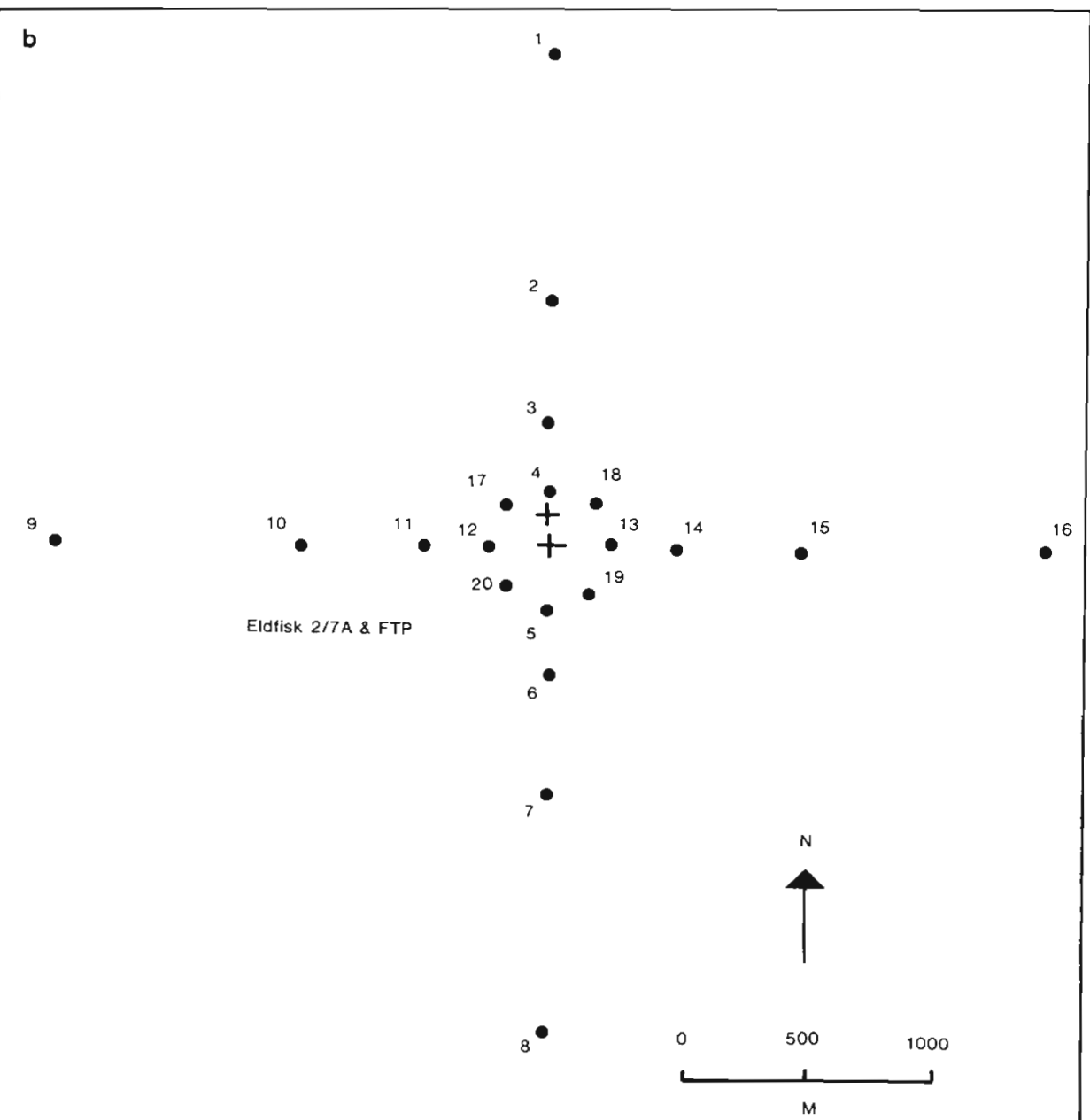


larity between the clusters, and species can be ranked by the magnitude of their contribution.

The analyses were run on an IBM PS/2 using the program adapted for MS-DOS by staff at the Plymouth Marine Laboratory (M. R. Carr and K. R. Clarke). Site groupings determined from the above analysis were used to group the environmental data, which were then analysed by standard univariate statistics using the Statgraphics Package (STSC 1986).

Recently Heip et al. (1988) and Warwick (1988) have suggested that higher taxa (genera and families) are as efficient in discriminating between sites as the traditional species set. We therefore tested the sensitivity of the multivariate techniques used on a traditional species-site matrix using quantitative data against presence-absence data and against data aggregated into higher taxa (families, phyla and only the 4 dominant phyla - Annelida, Mollusca, Arthropoda and Echinodermata)

\section{RESULTS}

\section{Ekofisk field}

The dominant sediment type from all sites was within the fine or very fine sand on the Wentworth scale, with a phi range of 2.83 to 3.30 \$. Mud content was significantly higher near the platform (see later analysis). Table 1 shows the site data for species and individual number and diversity.

The sites within $500 \mathrm{~m}$ of the platform tended to have higher numbers of individuals and lower diversity than sites without, although there is in fact no significant difference (using an analysis of variance on $\log _{10^{-}}$ transformed data) in diversity between 0 to $500 \mathrm{~m}$ sites and 500 to $1000 \mathrm{~m}$ sites. Otherwise there are no clear differences between number of taxa, number of individuals or diversity

Plots of individuals among species (Fig. 2) along a transect of stations across the Ekofisk field shows that, within $100 \mathrm{~m}$ of the platform, at Stns 30 and 37 there are signs of disturbed assemblages (the number of rare species at the abscissa tend to decrease, there are 1 or 2 frequencies in the high abundance classes and perhaps a suggestion that the smooth curves become more jagged, indicating a general disturbance to normal abundance patterns). Stn 18 (2000 m from the Ekofisk central complex) has a reduced number of rare species and a jagged curve but does not have a high number of individuals. The plots suggest that this site is disturbed but not as much as Stns 30 and 37 . Extracting indicator species (species occurring in geometric classes $V$ to VI at the unpolluted sites; see Gray \& Pearson 1982) gives the plots shown in Fig. 3. The overall pattern is of a decrease in abundance to the most polluted stations with Goniada maculata showing a slight increase from background before a decline. Using an ANOVA test on log-transformed data, Abra prismatica and Nephtys longosetosa show a significant decrease in mean abundance closer than $500 \mathrm{~m}$ from the platform (Stns 30,37 and 31 compared with Stns 28 and 33) whereas G. Maculata and Eudorellopsis deformis have significantly lower abundances at Stns 30 and 37 than at Stns 28 and 33 for $G$. maculata and 29 and 1 for E. deformis.

Fig. 4 a shows the classification analysis for the Ekofisk quantitative data and Fig. $4 \mathrm{~b}$ the MDS ordination of the same pooled replicate data. There are 4 clear groupings with, in the MDS analysis (Fig. 4b), sites grading from those closest to the installation at the right hand side (D) to those furthest away at the left hand side (A). Plotting these groups on the original sampling sites (Fig. 5) shows that there is a clear gradient of effects with a demarcation at a radius of 2 to $3 \mathrm{~km}$ between site groups $\mathrm{A}$ and $\mathrm{B}$ and another strong change within $500 \mathrm{~m}$ of the $2 / 4 \mathrm{~B} \& \mathrm{~K}$ platforms (groups C and D).

In order to determine whether or not the site groupings were related to effects of oil-related activities, site groups were plotted against total hydrocarbon concentration (THC), barium content of sediment and \% of mud ( $<63 \mu \mathrm{m}$ particles). In the drilling process barite is used and is discharged in the drilling muds. Barium is not regarded as a toxic chemical for marine benthos and is not, as far as is known, metabolised. Thus the barium content of the sediments can be used as a tracer for drilling muds.

Fig. 6 shows the results with $95 \%$ confidence intervals. A $\log _{e}(\mathrm{x}+1)$ transformation was used for $\mathrm{THC}$ and barium to remove a dependence of standard deviation on mean in the raw data, and thus validate the ANOVA tests of differences between groups. There is a clear relationship between the species groups and the $\%$ mud, THC and barium content. Oil-based drilling muds are the largest single contaminant discharged from oil platforms and clearly the benthic fauna is responding to this contamination. Site group $C$ has significantly higher \% mud than groups $A$ and $B$ although the level of THC is not significantly higher. For THC there is a gradient from the unpolluted $\mathrm{A}$ group of sites with background levels of THC to the grossly polluted D group of sites with significantly higher THC levels. Site group A has significantly much lower barium content than site groups $B, C$ and $D$ and the barium levels at group $A$ are comparable to background values for the reference site (329 ppm). Group A sites, therefore, can be regarded as unpolluted or relatively so.

Based on their species composition the site groups can be sorted into a distinct gradient of contamination: site group $\mathrm{A}$ has low barium, low THC and low \% mud 
Table 1. Numbers of individuals, number of taxa and diversity for replicate grab samples at each site in July 1986 grouped in distances from platform. Numbers of individuals and taxa are per grab $\left[0.1 \mathrm{~m}^{2}\right]$ for the 3 replicates. Diversity: Shannon-Wiener index using logarithms to base e

\begin{tabular}{|c|c|c|c|c|c|c|c|c|}
\hline Sites & \multicolumn{3}{|c|}{ No. ind. } & \multicolumn{3}{|c|}{ No. taxa } & \multicolumn{2}{|c|}{ Mean diversity } \\
\hline \multicolumn{9}{|c|}{$0-500 \mathrm{~m}$} \\
\hline 30 & 501 & 357 & 376 & 35 & 33 & 33 & & 1.70 \\
\hline 36 & 405 & 286 & 500 & 42 & 36 & 39 & & 1.93 \\
\hline \multirow[t]{2}{*}{37} & 409 & 417 & 457 & 49 & 46 & 41 & & 1.55 \\
\hline & \multicolumn{3}{|c|}{ Mean 412} & & Total 5 & & Mean & 1.73 \\
\hline \multicolumn{9}{|c|}{$500-1000 \mathrm{~m}$} \\
\hline 3 & 257 & 355 & 301 & 42 & 39 & 40 & & 2.09 \\
\hline 25 & 327 & 316 & 279 & 39 & 43 & 40 & & 2.32 \\
\hline 26 & 302 & 347 & 334 & 42 & 40 & 43 & & 1.95 \\
\hline 27 & 271 & 394 & 335 & 31 & 38 & 38 & & 1.61 \\
\hline 31 & 381 & 293 & 257 & 48 & 41 & 35 & & 2.28 \\
\hline \multirow[t]{2}{*}{35} & 154 & 182 & 212 & 41 & 36 & 40 & & 2.91 \\
\hline & \multicolumn{3}{|c|}{ Mean 294.3} & & Total 10 & & Mean & 2.20 \\
\hline \multicolumn{9}{|c|}{$1000-3000 \mathrm{~m}$} \\
\hline 2 & 205 & 81 & 130 & 36 & 33 & 36 & & 2.54 \\
\hline 4 & 103 & 150 & 114 & 38 & 38 & 32 & & 2.88 \\
\hline 8 & 121 & 302 & 290 & 38 & 37 & 42 & & 2.23 \\
\hline 9 & 58 & 302 & 335 & 33 & 44 & 48 & & 2.32 \\
\hline 13 & 78 & 221 & 191 & 36 & 37 & 39 & & 2.51 \\
\hline 14 & 163 & 257 & 197 & 41 & 49 & 39 & & 2.46 \\
\hline 15 & 264 & 441 & 361 & 43 & 46 & 44 & & 1.95 \\
\hline 18 & 194 & 289 & 356 & 34 & 38 & 36 & & 1.62 \\
\hline 19 & 239 & 209 & 271 & 30 & 37 & 37 & & 1.82 \\
\hline 21 & 155 & 231 & 220 & 31 & 28 & 29 & & 1.71 \\
\hline 22 & 196 & 144 & 467 & 41 & 36 & 40 & & 2.22 \\
\hline 23 & 320 & 284 & 271 & 44 & 34 & 40 & & 2.00 \\
\hline 24 & 272 & 328 & 206 & 34 & 38 & 31 & & 1.71 \\
\hline 28 & 346 & 305 & 299 & 39 & 39 & 35 & & 1.75 \\
\hline 29 & 249 & 67 & 230 & 30 & 22 & 35 & & 1.73 \\
\hline 32 & 276 & 129 & 361 & 42 & 32 & 40 & & 1.99 \\
\hline 33 & 247 & 148 & 216 & 41 & 31 & 45 & & 2.31 \\
\hline 34 & 436 & 424 & 362 & 43 & 41 & 39 & & 1.75 \\
\hline 38 & 409 & 417 & 457 & 49 & 46 & 41 & & 1.85 \\
\hline \multirow[t]{2}{*}{39} & 364 & 255 & 215 & 39 & 32 & 37 & & 1.58 \\
\hline & \multicolumn{3}{|c|}{ Mean 253.8} & & Total 1 & & Mean & 2.05 \\
\hline \multicolumn{9}{|c|}{$>3000 \mathrm{~m}$} \\
\hline 1 & 108 & 92 & 144 & 35 & 30 & 28 & & 2.56 \\
\hline 5 & 66 & 84 & 113 & 24 & 30 & 40 & & 2.98 \\
\hline 6 & 178 & 116 & 207 & 33 & 28 & 34 & & 2.15 \\
\hline 7 & 190 & 249 & 218 & 37 & 38 & 29 & & 1.81 \\
\hline 10 & 140 & 218 & 241 & 35 & 30 & 29 & & 2.05 \\
\hline 11 & 193 & 272 & 254 & 36 & 38 & 33 & & 1.64 \\
\hline 16 & 118 & 169 & 242 & 29 & 22 & 32 & & 1.84 \\
\hline 17 & 285 & 169 & 64 & 31 & 28 & 29 & & 1.90 \\
\hline 20 & 79 & 251 & 189 & 28 & 30 & 31 & & 1.87 \\
\hline \multirow[t]{2}{*}{21} & 155 & 231 & 220 & 31 & 28 & 29 & & 1.71 \\
\hline & \multicolumn{3}{|c|}{ Mean 152.0} & & Total 11 & & Mean & 2.05 \\
\hline
\end{tabular}

content $(<4 \%)$; site group $B$ has high barium, low THC and low \% mud $(<4 \%)$; site group $\mathrm{C}$ has high barium, low THC and medium $\%$ mud $(7 \%)$; site group $\mathrm{D}$ has high barium, high THC and high $\%$ mud $(12 \%)$

The classification and MDS analyses were re-run using only presence and absence data (Fig. 7). The results show that the unpolluted site groups ( $a$ and $b$ ) have a virtually identical grouping of sites to group $A$ in the quantitative analysis. However, using only presence and absence data it is not possible to distinguish clearly between groups $B$ and $C$ in the original quantitative analysis (the large group $c$ here). The polluted group (d) includes Stns 30 and 37 as in the quantitative analysis. Thus the presence and absence data distin- 

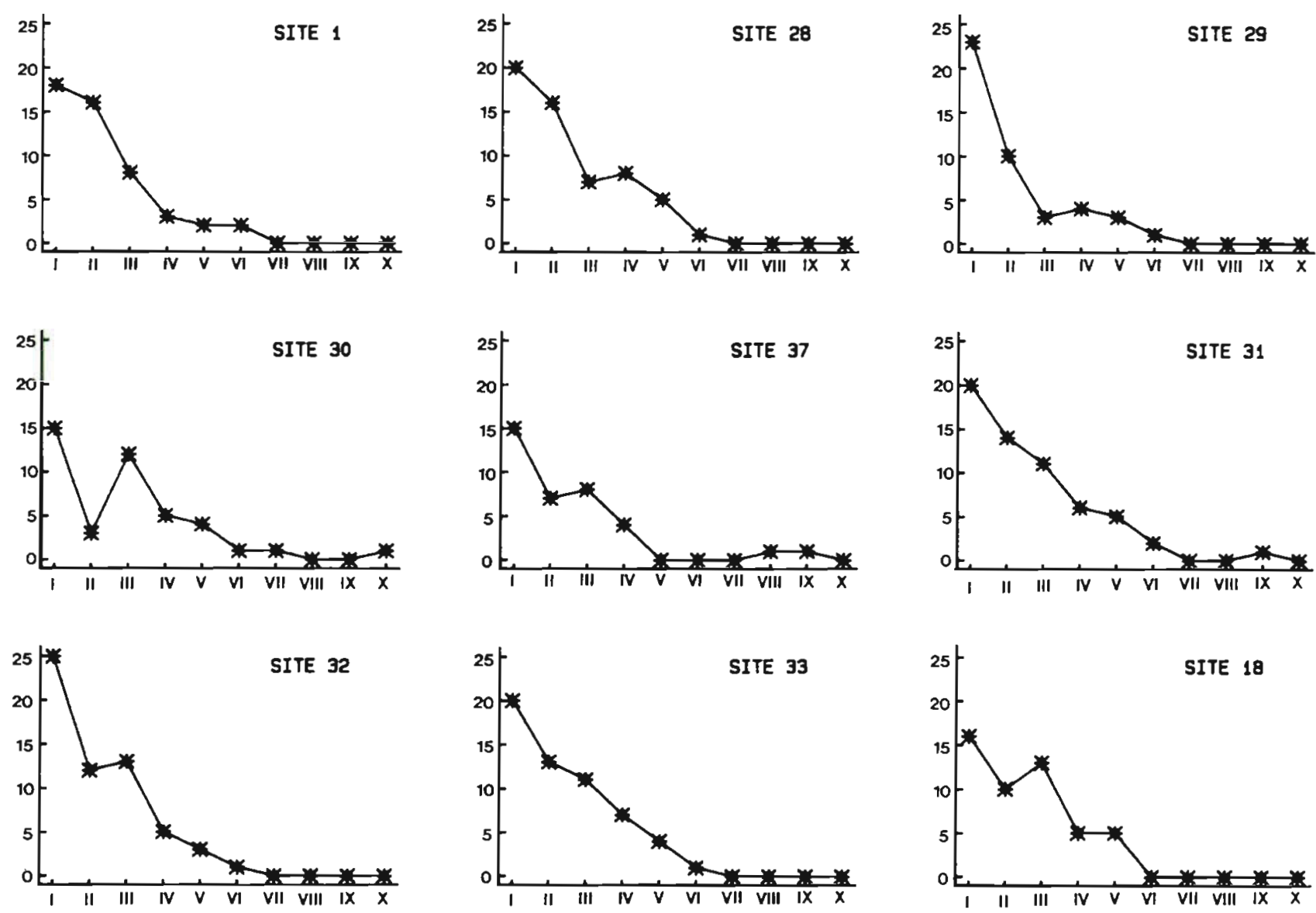

Fig. 2. Plots of number of individuals per species. Y-axis: number of species; X-axis: number of individuals per species in geometric classes (class I $=1$ ind. sp. ${ }^{-1}$; class II $=2$ to 3 ind. sp. ${ }^{-1}$; class III $=3$ to 7 ind. sp. ${ }^{-1}$, class IV $=8$ to 15 ind. sp. ${ }^{-1}$; etc.)

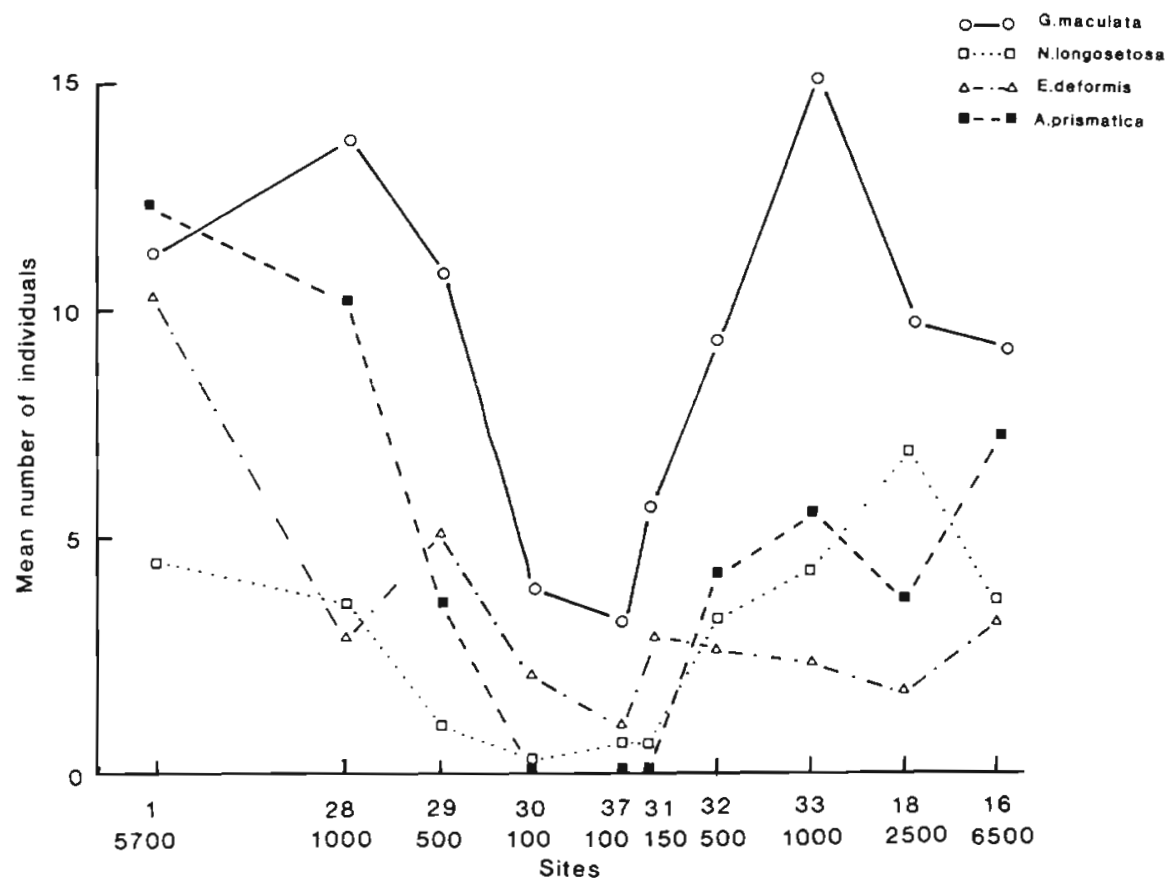

Fig. 3. Transect across Ekofisk field showing 4 species occurring in geometric classes $\mathrm{V}$ and $\mathrm{VI}$ at the unpolluted sites. Y-axis: number of individuals per $0.3 \mathrm{~m}^{2}$; $\mathrm{X}$-axis: station numbers (upper) and distance from central complex in $\mathrm{m}$ (lower). For clarity $95 \%$ CIs have been omitted 

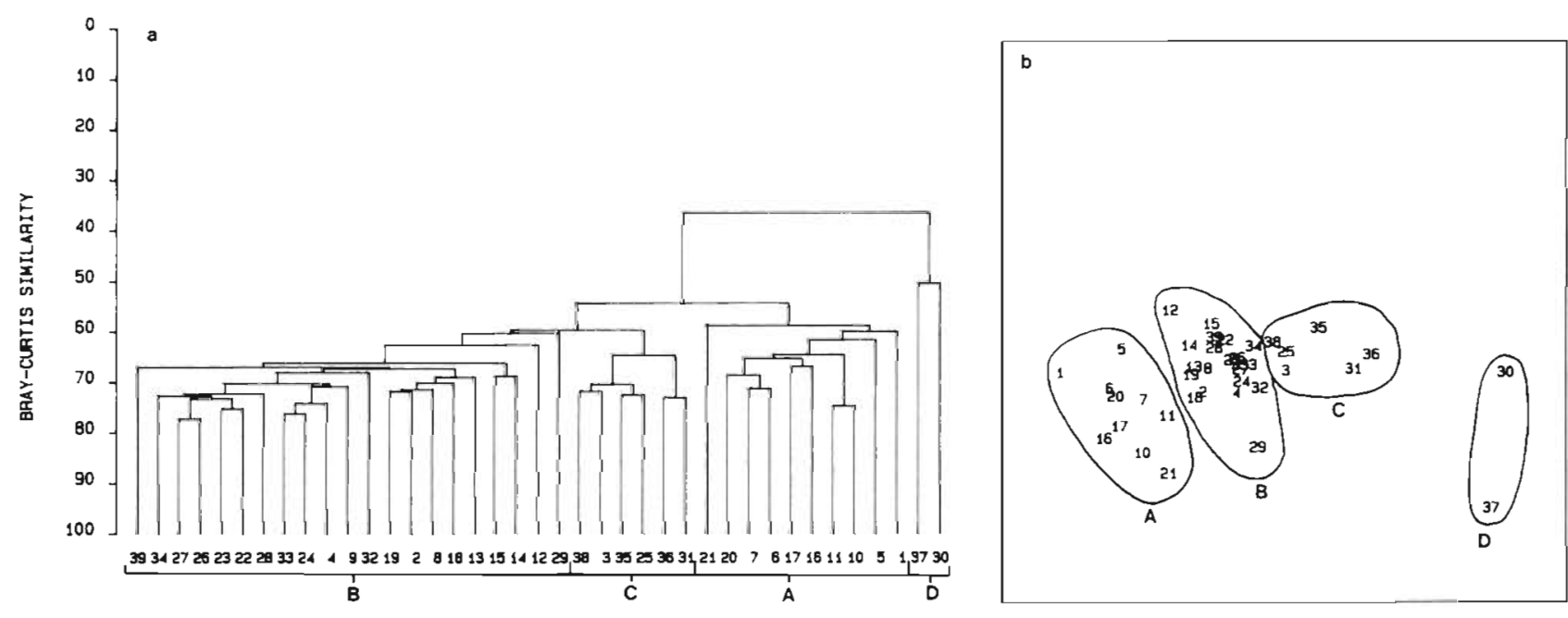

Fig. 4. Ekofisk quantitative data ( $V$ transformed). (a) Classification analysis; (b) MDS ordination (stress $=0.12$ ). Numbers refer to sites (Fig. 1a); letters to groups of stations separated at $62 \%$ dissimilarity level, except for group D where 2 sites are separated only at $50 \%$ level

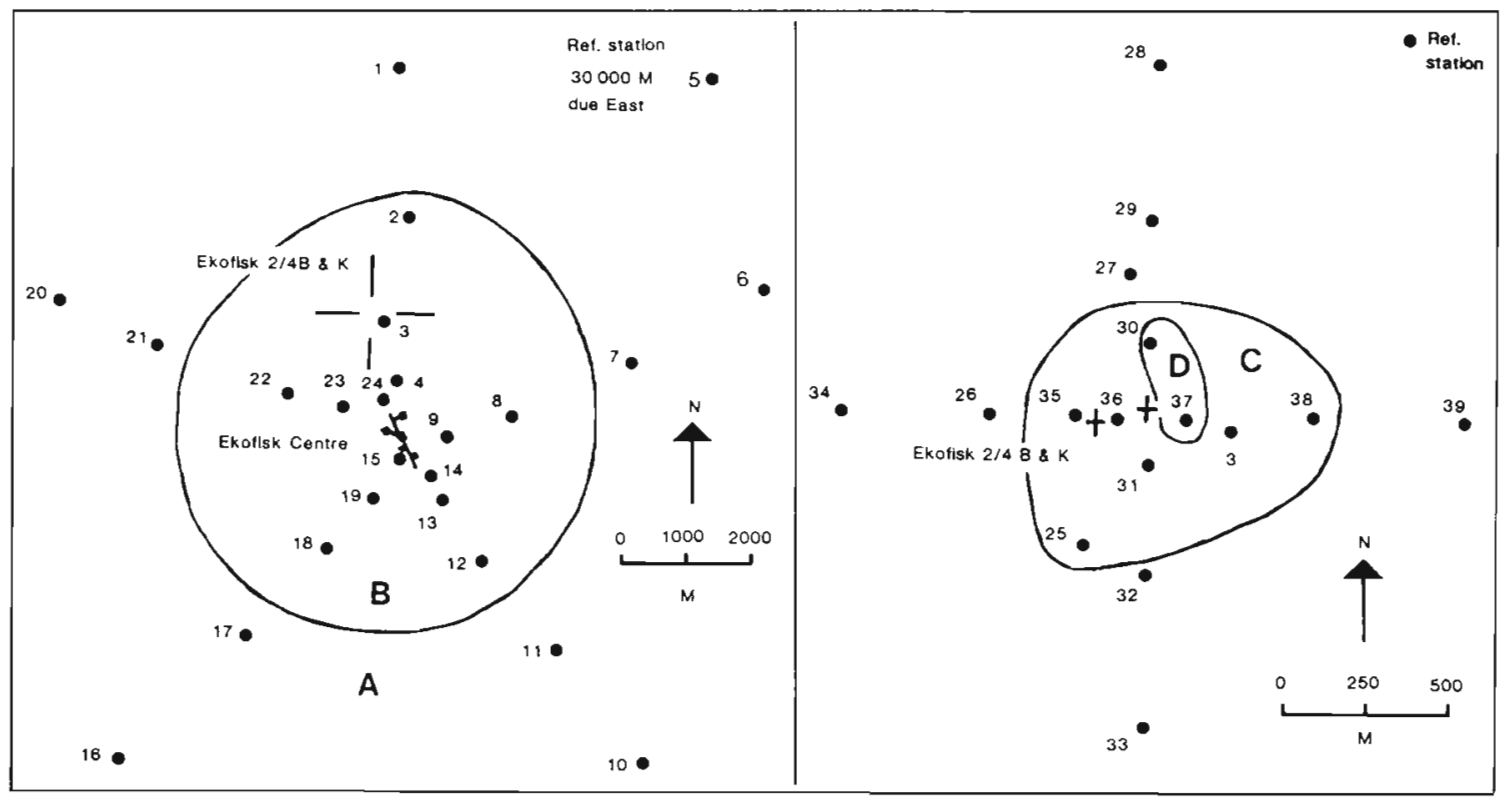

Fig. 5. Ekofisk. Plots of groups from multivariate analyses on original sites. Letters refer to groups from classification analysis (Fig. 4a)

guishes the unpolluted ( $\mathrm{a}$ and $\mathrm{b}$ ) from the intermediate (c) and grossly polluted (d) sites.

In order to test which species account for the site groupings, the top 15 species were ranked in decreasing order of contributions to the average dissimilarity between a pair of groups. Firstly the quantitative species data are analysed.

Table 2 shows that groups A and B are most similar (dissimilarity $=43.33 \%$ ) whereas D and A are the most dissimilar (69.06\%). The main quantitative difference between groups $A$ and $B$ is that 12 of the 15 highest ranked species accounting for the difference between $A$ and $B$ increased in abundance in $B$ compared with $A$. The species that increased in abundance from $A$ to $B$ were: Ophiura affinis, Chaetozone setosa, Myriochele spp., Asteroidea indet., Ampharete baltica, Amphictene auricoma, Pholoe inornata, Lunatia montagui, Anobothrus gracilis, Chaetoderma nitidulum, Lum. brinereis spp. and Goniada maculata. Only Montacuta substriata, Glycera alba and Ampelisca macrocephala decreased in abundance from A to B, although $G$. alba increased again at $C$ and $D$. Numbers of $G$. alba were 

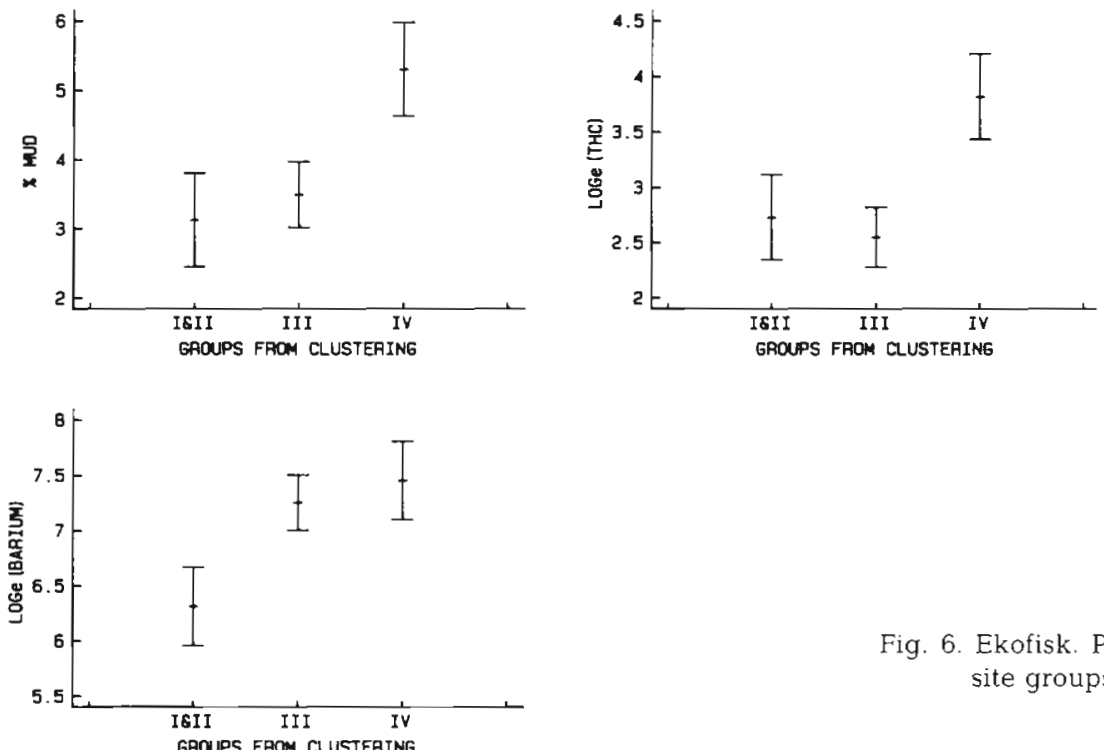

Fig. 6. Ekofisk. Plots of selected environmental data against site groups from classification analysis (Fig. 4a)
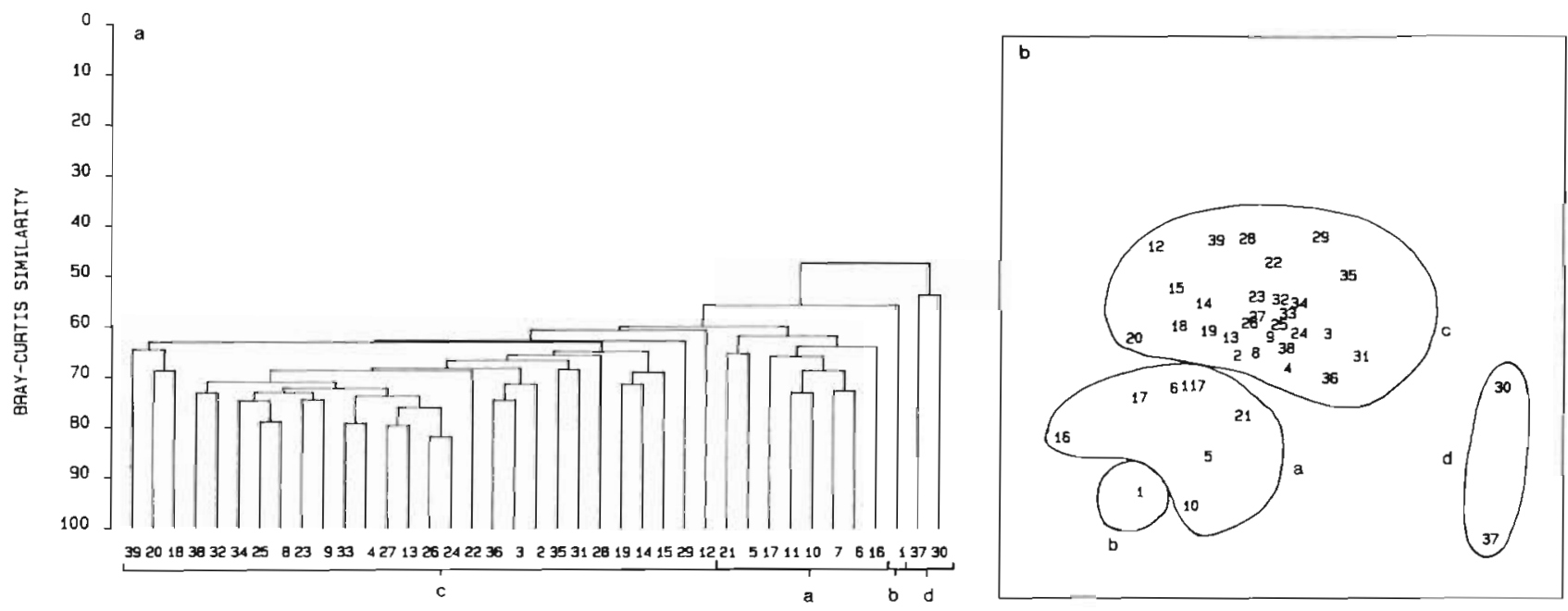

Fig. 7. Ekofisk presence-absence data. (a) Classification analysis; (b) MDS ordination (stress $=0.21$ ). Numbers refer to sites (Fig. 1a); letters to groups of stations separated at $60 \%$ dissimilarity level, except for group d where the 2 sites are separated only at $50 \%$ level

low within all groups and no significance can be attached to abundance changes in this species.

Between $A$ and $C$ differences were accentuated compared with the $\mathrm{A}: \mathrm{B}$ comparison as the $\delta_{j}$ increased with 6 values being greater than the maximum between $A$ and $B$ (1.31). The abundance of Chaetozone setosa increased dramatically from an average of 1.5 individuals to 185.3 (and continued to D, 460 individuals). Pholoe inornata and Ophiura affinis also increased from $A \rightarrow B \rightarrow C$ from 5.1 to 15.5 to 49.7 individuals and from 6.2 to 19.5 to 32.2 individuals respectively. In addition Eteone longa, Minuspio cirrifera, Hippomedon denticulatus and Philine quadrata, not among the 15 most important species accounting for differences between $A$ and $B$, were now important.
Between $A$ and $D$, apart from the large increase in abundance of Chaetozone setosa already mentioned, Capitella capitata, not present at the other sites, showed a dramatic increase in abundance as did the amphipod Jassa marmorata. The other feature of the comparison between the unpolluted group $A$ and the highly polluted $D$ site was the absence of 5 of the dominant 15 species present at A. These were Montacuta substriata, Abra prismatica, Sthenhelais limicola, Amphiura filiformis and Scoloplos armiger.

In analysing between-group dissimilarities for the presence and absence data (analysis not shown), the most clear-cut (and expected) finding was that the consistently high abundance species in the quantitative comparison did not now contribute to intergroup 
Table 2. Ekofisk data: principal species contributing to differences of groups B, C, D from group A. Average species abundances across sites within each of the 4 clusters $A$ to $D$; also the contribution $(D$, of the $i$ th species to the average Bray-Curtis $\checkmark$-transformed dissimilarity $(\bar{\delta})$ between pairs of groups (B:A, C:A, D:A)

\begin{tabular}{|c|c|c|c|c|c|c|c|}
\hline \multirow[t]{2}{*}{ Species } & \multirow{2}{*}{$\begin{array}{c}\text { A } \\
\text { Av. abd. A }\end{array}$} & \multicolumn{2}{|c|}{$B: A$} & \multicolumn{2}{|c|}{$C: A$} & \multicolumn{2}{|c|}{$D: A$} \\
\hline & & Av. abd. B & $O,(B: A)$ & Av. abd. C & $\partial_{1}(\mathrm{C}: \mathrm{A})$ & Av. abd. D & $\delta_{1}(D: A)$ \\
\hline Montacuta substriata & 9.5 & 1.9 & 1.31 & 0 & 1.28 & 0 & 1.48 \\
\hline Ophiura affinis & 6.2 & 19.48 & 1.18 & 32.17 & 1.57 & & \\
\hline Chaetozone setosa & 1.5 & 11.62 & 1.06 & 185.33 & 4.93 & 460.00 & 9.69 \\
\hline Myriochele spp. & 4.8 & 15.43 & 1.04 & 12.50 & 0.80 & & \\
\hline Asteroidea indet. & 2.1 & 11.57 & 1.03 & & & & \\
\hline Ampharete baltica & 1.5 & 10.86 & 1.01 & 22.67 & 1.62 & & \\
\hline Amphictene auricola & 0.5 & 7.24 & 1.00 & & & & \\
\hline Pholoe inornata & 5.1 & 15.52 & 0.83 & 49.67 & 2.11 & & \\
\hline Lunatia montagui & 0.3 & 3.71 & 0.77 & 10.00 & 1.26 & 20.00 & 1.87 \\
\hline Anobothrus gracilis & 1.4 & 6.57 & 0.77 & 11.00 & 1.00 & & \\
\hline Glycera alba & 4.6 & 2.76 & 0.76 & 8.17 & 1.07 & 6.00 & 1.11 \\
\hline Chateoderma nitidulum & 3.3 & 7.57 & 0.72 & & & & \\
\hline Lumbrinereis spp. & 0.1 & 2.81 & 0.71 & 6.50 & 0.99 & & \\
\hline Goniada maculata & 28.2 & 35.52 & 0.68 & & & 11.00 & 1.21 \\
\hline Ampelisca macrocephala & 7.2 & 4.76 & 0.67 & & & & \\
\hline Abra prismatica & 25.5 & & & 6.50 & 1.51 & 0 & 2.54 \\
\hline Eteone longa & 0.2 & & & 12.00 & 1.34 & & \\
\hline Munispio cirrifera & 6.5 & & & 28.17 & 1.23 & & \\
\hline Hippomedon denticulatus & 0 & & & 9.83 & 0.87 & & \\
\hline Philine quadrata & 0.3 & & & 4.83 & 0.80 & & \\
\hline Capitella capitata & 0 & & & & & 167.00 & 5.49 \\
\hline Jassa marmorata & 0 & & & & & 43.00 & 2.66 \\
\hline Sthenelais limicola & 8.3 & & & & & 0 & 1.45 \\
\hline Amphiura filiformis & 8.4 & & & & & 0 & 1.42 \\
\hline Copepod indet. & 4.0 & & & & & 19.00 & 1.30 \\
\hline Pleurogonidae indet. & 1.2 & & & & & 14.5 & 1.29 \\
\hline Philine scabra & 0.9 & & & & & 9.0 & 1.12 \\
\hline Scoloplos armiger & 5.2 & & & & & 0 & 1.11 \\
\hline Nephtys longisetosa & 11.2 & & & & & 1.5 & 1.05 \\
\hline Av. dissimilarity $\bar{\delta}$ & & & 43.33 & & 53.73 & & 69.06 \\
\hline
\end{tabular}

differences. Between $A$ and $B$, of the 40 most significant species in the quantitative analysis only 7 occurred in the top 40 species contributing to the presenceabsence comparison. Of the top 15 species accounting for the difference between $A$ and $B$ in the presenceabsence data, all species were present in both groups. The difference therefore arises from the fact that these species are absent from most sites in one group and present at most sites in the other group. In addition 46 species were present in $B$ and not in $A$ and 11 species present in $\mathrm{A}$ and not in $\mathrm{B}$.

Between $A$ and $C$, of the top 15 ranked species 2 species are present in C but not in A (Jassa marmorata, Hippomedon denticulatus), both amphipods which are supposed to respond negatively to oil (Dauvin \& Gentil 1990). Three species occur in A and not in C (Montacuta substriata, and Harmothoe castanea and Virgularia mirabilis). There were 25 species present in C and not in A and 34 species present in A and not in C. Between $A$ and $D$ this trend is accentuated with, of the top 15 ranked species, 2 species present in D and absent in A ( $J$. marmorata and the opportunist species Capitella capitata) and 5 species of the top 15 ranked species present in $\mathrm{A}$ being absent in $\mathrm{D}$ (Amphiura filiformis, Scoloplos armiger, Abra prismatica, M. substriata, and Sthenhelais limicola). Only 14 species were present in $D$ and absent in $A$, but 70 species present in A were absent in $\mathrm{D}$.

It is not surprising that the presence-absence data cannot distinguish between groups $\mathrm{B}$ and $\mathrm{C}$ since only 8 of the top 15 ranked species from the quantitative analysis were among the top 30 in the presenceabsence list and no species among the top 30 were present in one group and wholly absent in the other.

\section{Eldfisk field}

Data analyses for the Eldfisk field showed similar findings to those at Ekofisk with number of individuals, number of species and diversity showing effects only in the immediate area of the platform (Hobbs 1987). Use 
of these characteristics to assess effects of oil contamination is not particularly sensitive. Therefore, only the classification and ordination analyses are shown (Fig. 8a, b).

Four groups of sites can be distinguished. Plots of these groupings on the orginal sites (Fig. 9) shows that the division between site groups I and II and the largest group III occurs at between 1 and $2 \mathrm{~km}$ on 3 of the 4 axes and between 0.5 and $1 \mathrm{~km}$ on the other axis. It is convenient to group the 2 small outer groups, I and II, to retain reasonable sample sizes for statistical purposes, and this is done in the following analyses. Plotting the $\%$ mud, THC content and barium content and their $95 \%$ CI's (Fig. 10) shows similar results to those of Fig. 6. The most contaminated sites have a significantly higher mud and THC content than the other site
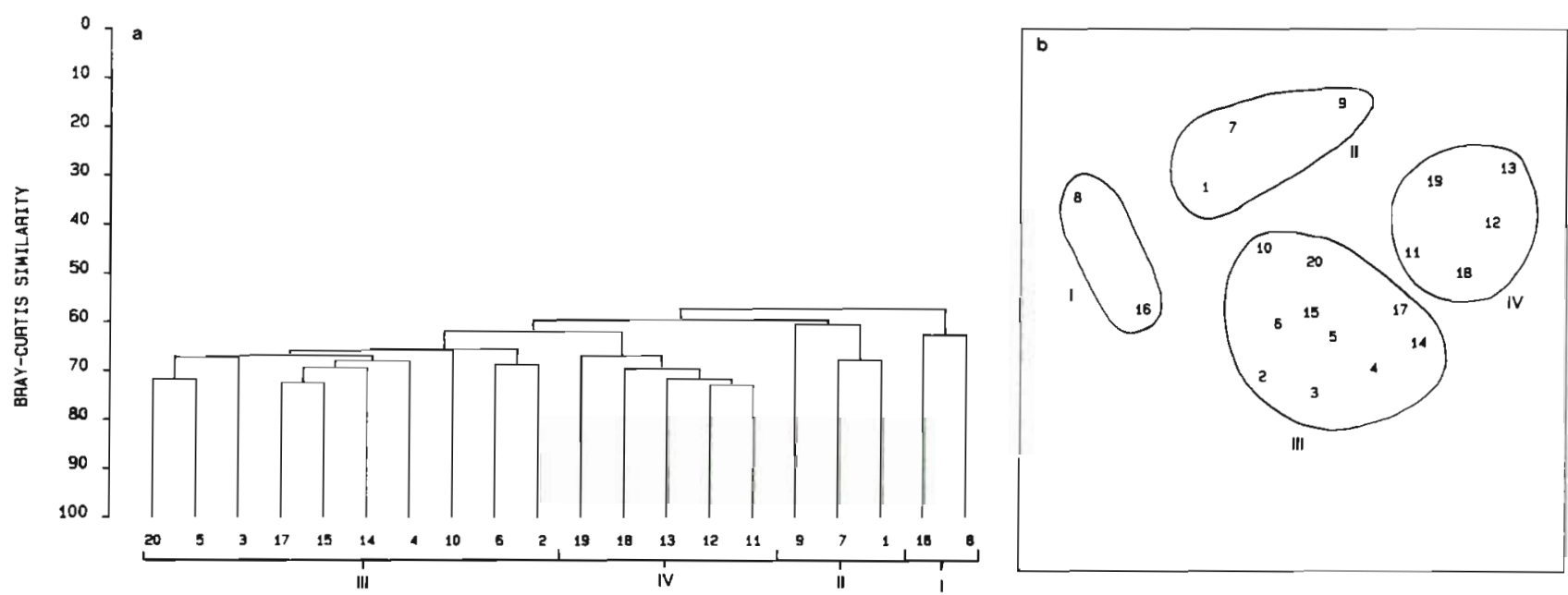

Fig. 8. Eldfisk quantitative data ( $\vee$ transformed). (a) Classification analysis; (b) MDS analysis (stress $=0.18$ ). Numbers refer to sites (Fig. 1b), roman numerals to site groups separated at $62 \%$ dissimilarity (I and II) and $65 \%$ dissimilarity (III and IV)

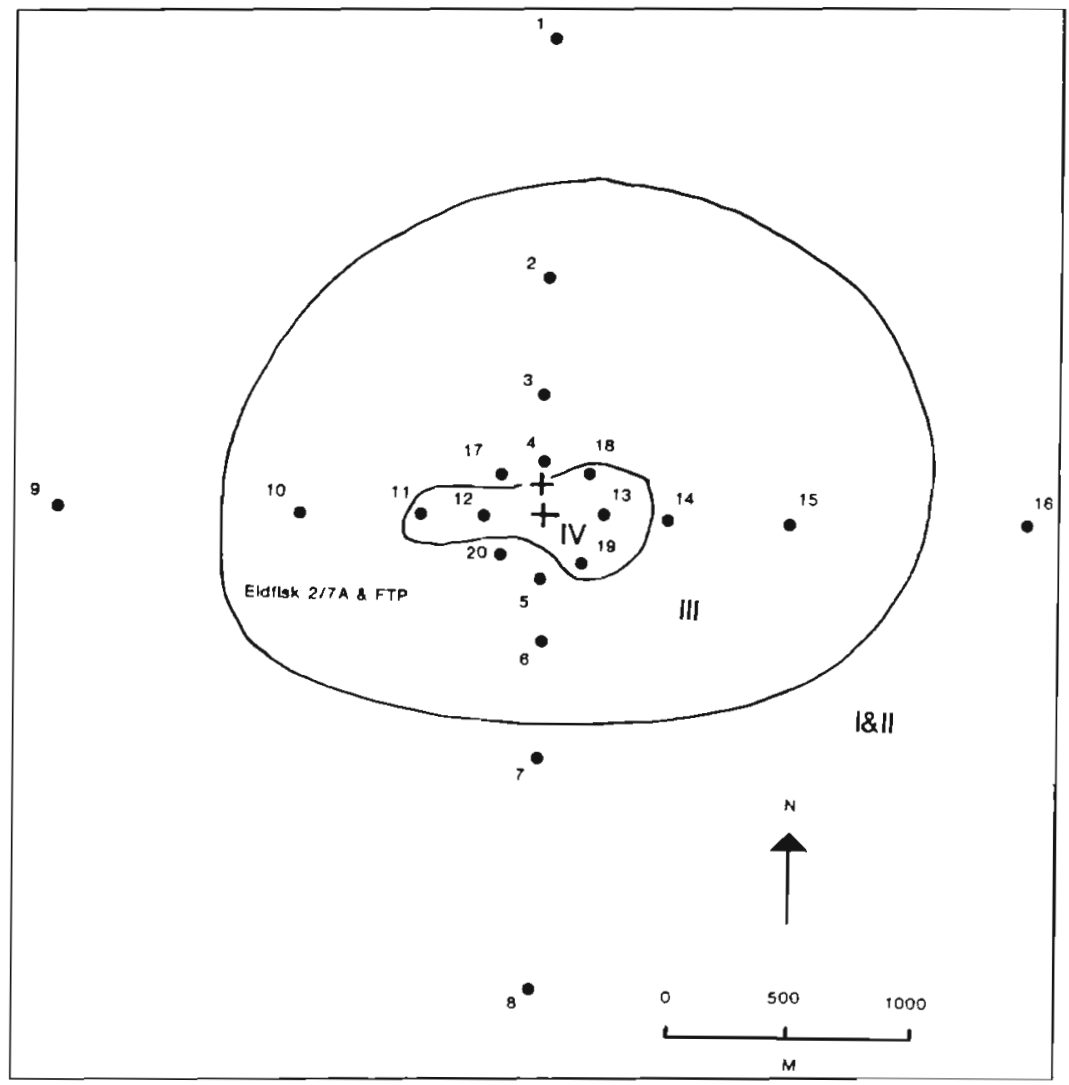

Fig. 9. Eldfisk. Plots of groups from multivariate analyses on original sites. Roman numerals refer to site groups from classification analysis (Fig. 8a) 

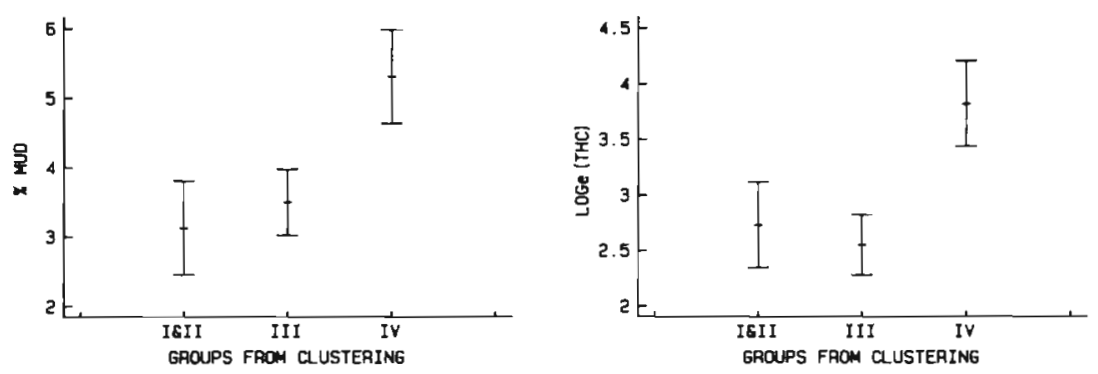

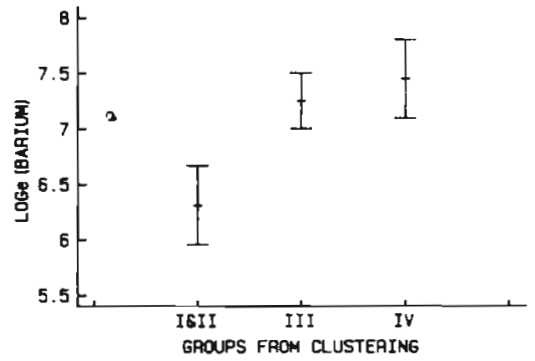

groups, but the unpolluted group has a lower barium content. Again the barium content is an excellent correlate of the split between unpolluted and the first stages of contamination (i.e. between groups I, II and III). Compared with the Ekofisk data (Fig. 6) and using the barium, THC and \% mud data the ranking from unpolluted to polluted is $A \& I \& I I<B \&$ III $<$ IV $<C<$ D.

Table 3 shows species changes. The overall dissimilarity between groups I, II and III is $40.3 \%$ and between I \& II and IV is $43.6 \%$, compared with $43.3 \%$
Fig. 10. Eldfisk. Plots of selected environmental data against site groups from multivariate analyses (Fig. 8a)

between $\mathrm{A}$ and $\mathrm{B}$ and $53.7 \%$ between $\mathrm{A}$ and $\mathrm{C}$ at Ekofisk. One can expect, therefore, that differences in species abundances and presence-absence patterns between groups I \& II and III and I \& II and IV will be less than between $\mathrm{A}$ and $\mathrm{B}$ and $\mathrm{A}$ and $\mathrm{C}$.

Comparing groups I \& II with III, 10 of the top ranked 15 species in Table 3 showed increased abundances in group III compared with I \& II (Asteroidea indet., Myriochele spp., Ophiura affinis, Corophium crassicorne, Owenia fusiformis, Astropecten irregularis, Timoclea ovata, Artica islandica, Ampharete finnmar-

Table 3. Eldfisk data (for explanation see Table 2 legend)

\begin{tabular}{|c|c|c|c|c|c|}
\hline \multirow{2}{*}{ Species } & \multirow{2}{*}{$\begin{array}{c}\text { I \& II } \\
\text { Av. abd. I \& II }\end{array}$} & \multicolumn{2}{|c|}{ III:I \& II } & \multicolumn{2}{|c|}{ IV:I \& II } \\
\hline & & Av. abd. III & $\delta_{i}(\mathrm{III}: \mathrm{I} \& \mathrm{II})$ & Av. abd. IV & $\delta_{i}(\mathrm{IV}: \mathrm{I} \& \mathrm{II})$ \\
\hline Montacuta substriata & 12.6 & 0 & 1.45 & 0 & 1.50 \\
\hline Asteroidea indet. & 3.0 & 11.9 & 1.04 & 11.0 & 1.02 \\
\hline Tmetonyx cicada & 9.8 & 0.6 & 1.01 & 3.8 & 1.10 \\
\hline Myriochele spp. & 10.8 & 18.9 & 0.97 & 8.2 & 0.83 \\
\hline Ophiura affinis & 5.8 & 13.9 & 0.94 & 28.4 & 1.68 \\
\hline Corophium crassicome & 3.2 & 11.5 & 0.87 & 36.6 & 2.29 \\
\hline Owenia fusiformis & 0.4 & 3.1 & 0.74 & 2.4 & 0.63 \\
\hline Astropecten irregularis & 3.8 & 4.9 & 0.71 & 0.6 & 0.66 \\
\hline Timoclea ovata & 0 & 1.9 & 0.66 & 2.6 & 0.85 \\
\hline Harmothoe castanea & 2.4 & 0.3 & 0.61 & 0 & 0.70 \\
\hline Arctica islandica & 1.2 & 1.6 & 0.57 & & \\
\hline Ampharete finmarchica & 0.8 & 3.2 & 0.55 & & \\
\hline Ampelisca macrocephala & 2.0 & 3.7 & 0.53 & 7.2 & 0.85 \\
\hline Amphiura filiformis & 9.0 & 12.2 & 0.52 & & \\
\hline Nephthys spp. & 1.6 & 0.8 & 0.49 & & \\
\hline Abra prismatica & & & & 6.0 & 0.96 \\
\hline Anataides groenlandica & 0.6 & & & 3.8 & 0.70 \\
\hline Lunatia montaguj & 0.4 & & & 3.0 & 0.65 \\
\hline Tharyx spp. & 0.4 & & & 2.6 & 0.62 \\
\hline Average dissimilarity $\bar{\delta}$ & & & 40.30 & & 43.56 \\
\hline
\end{tabular}


chica, and Amphiura filiformis) and only 3 species (Montacuta substriata, Harmothoe castanea and Ampelisca macrocephala) show decreased abundances.

Comparing I \& II with IV, large increases in abundance of Corophium crassicorne and Ophiura affinis occurred at IV. Changes in species composition were small with only 2 of the top 15 ranked species accounting for the differences between groups being present at I \& II and absent at III, or vice versa. Between I \& II and IV, of the top 15 ranked species Harmothoe castanea and Montacuta substriata were present in I \& II and absent in IV. It seems likely therefore, that the degree of contamination at Eldfisk is less than that at Ekofisk. In order to test this hypothesis multivariate analyses were carried out on the combined Eldfisk and Ekofisk samples.

Fig. 11a shows the classification analysis with the Eldfisk stations numbered from 40 to 59 . The ordination (Fig. 11 b) clearly ranks the sites on the $X$-axis along a gradient of contamination with Stns 30 and 37 at Ekofisk being highly polluted. The $\mathrm{Y}$-axis separates areas reflecting community composition differences. The unpolluted group has both Ekofisk and Eldfisk site groups A and I and II combined. The most polluted sites at Eldfisk however (group $\mathrm{H}$ sites) do not extend along the pollution axis further than site group $F$ (= Ekofisk group B). Both sites have similar barium content: mean 881 ppm for Ekofisk group B sites and 860 ppm for Eldfisk group $H$ sites.

In summary, effects of oil-related activities are less at the Eldfisk site, probably reflecting the shorter time period that the field has been in operation. The affected area appears to stretch to a maximum of $1.5 \mathrm{~km}$ from the installation.

\section{Aggregation to higher taxa}

Here only the Ekofisk data were used. Fig. 12 shows the analyses of the data grouped into families rather than species. The most polluted site (Stn 37, group h) and the other heavily polluted sites $(30,31$ and 36 , group g) are clearly distinguished, as in the original analysis. The unpolluted sites (group e) are separated from the sites showing the first stages of pollution (group f). This separation corresponds to that between groups $A$ and $B$ in the species analysis.

Fig. 13 shows the results for analyses of phyla and Fig. 14 for only the 4 major phyla: polychaetes, molluscs, echinoderms and crustacea. The overall patterns are maintained even when simply using the abundances of the 4 major phyla (Fig. 14).

Some minor changes occur, notably that a further group (o) is determined. This group, comprising Stns 3 , $15,25,26,35,38$, was present as a sub-group of (j) in the phyla analysis, and to a lesser extent, as a subgroup of (f) in the family analysis, but is now more clearly split from the parent group.

\section{DISCUSSION}

Rapport et al. (1985) and Schindler (1987), in reviews of the effects of stress on assemblages, suggested that reduction in diversity, change in size structure to smallsized species and dominance by opportunists were clear and almost universal changes caused by stressors. In a recent review Gray (1989) has elaborated on these changes but suggested that the above 3 responses occur late in the sequence of responses to stressors. The
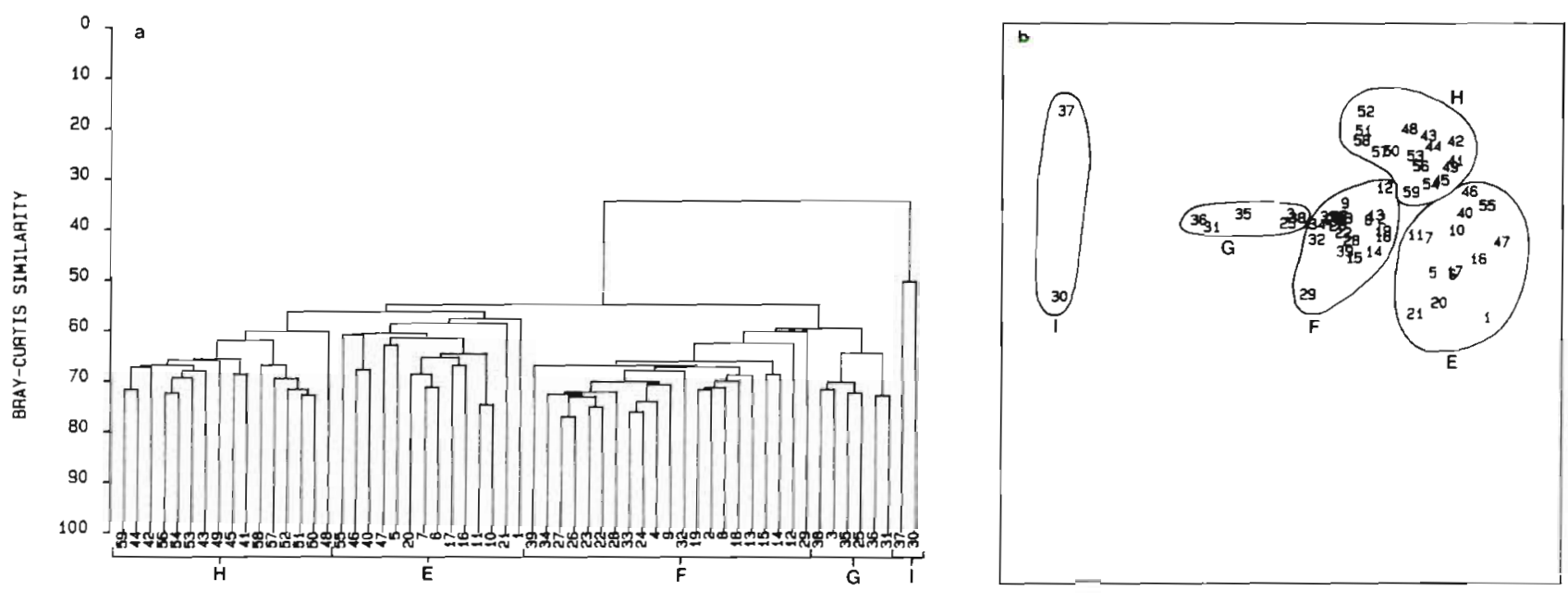

Fig. 11. Ekofisk and Eldfisk quantitative data combined ( $V$ transformed). (a) Classification analysis; (b) MDS ordination (stress = 0.15 ). Numbers refer to sites (Fig. 1a, b); letters to site groups separated at $57 \%$ dissimilarity, except for group I which is separated at $50 \%$ dissimilarity 

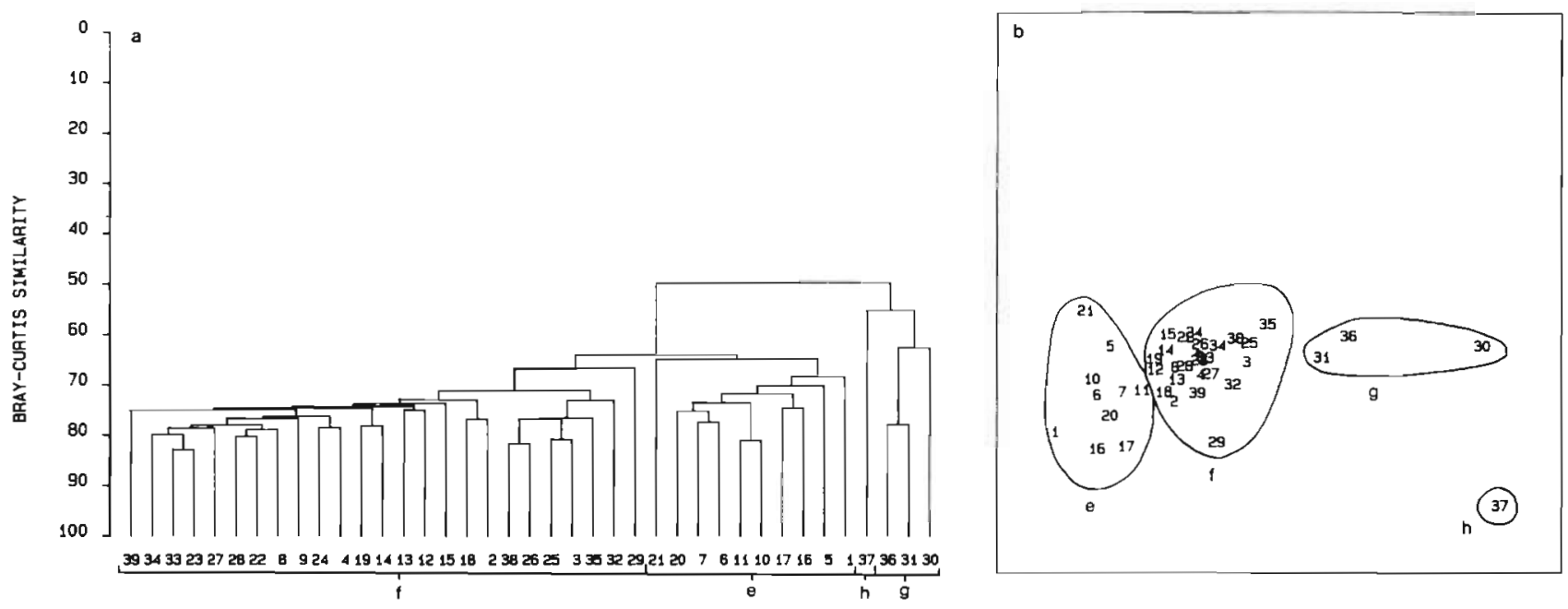

Fig. 12. Ekofisk quantitative data ( $V$ transformed) for families. (a) Classification analysis; (b) MDS ordination (stress = 0.11). Numbers refer to sites (Fig. 1a); letters to site groups separated at $65 \%$, except for group g which is separated at $62 \%$ dissimilarity
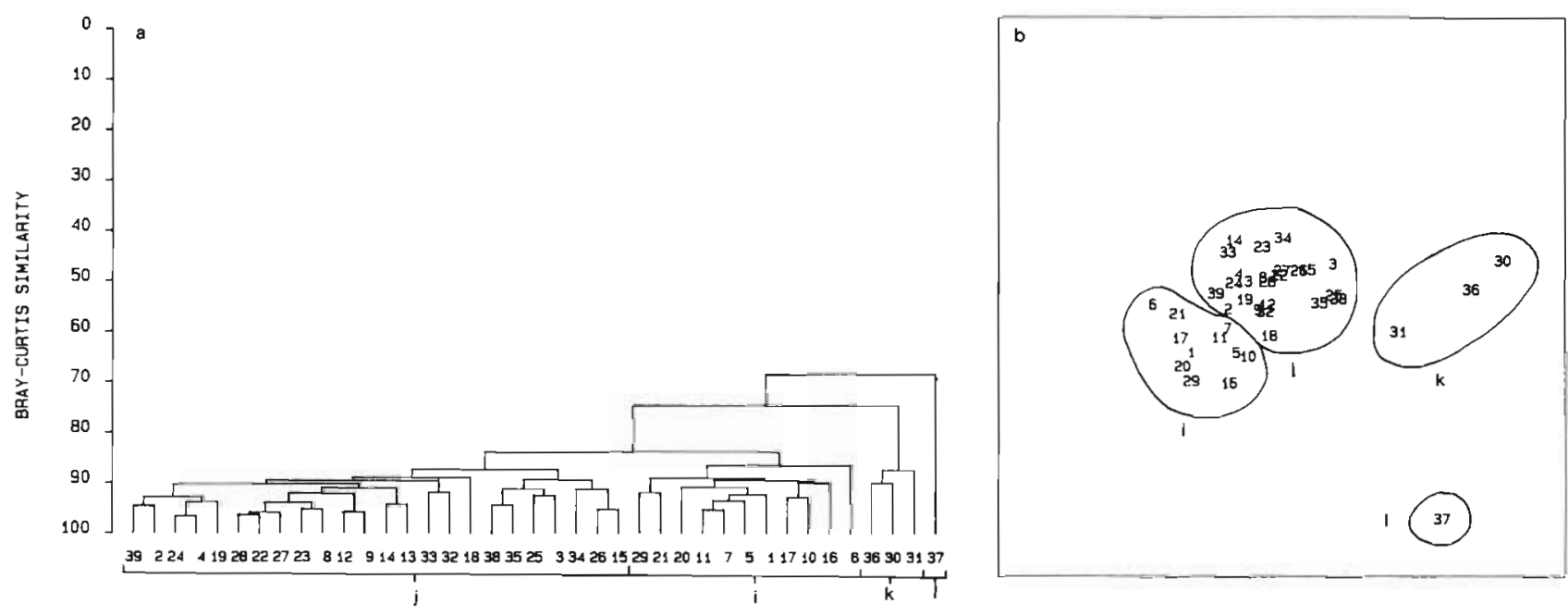

Fig. 13. Ekofisk quantitative data ( $V$ transformed) for phyla. (a) Classification analysis; (b) MDS ordination (stress = 0.13). Numbers refer to sites (Fig. 1a); letters to site groups separated at $85 \%$ dissimilarity

results obtained in this study strengthen these conclusions. Reductions in diversity and number of species and increased dominance of opportunists occurred only within 500 to $1000 \mathrm{~m}$ of the oil installations. Likewise, other methods which have been suggested as indicating stress in marine systems showed responses only close to the platforms. Plots of individuals among species (Gray \& Pearson 1982) were only able to suggest a distinction between the highly polluted group D sites and the unpolluted group A sites at Ekofisk. On this evidence alone, this method did not seem to be any more sensitive than use of diversity indices.

The multivariate techniques were more sensitive and clearly distinguished site groupings which could be related to oil activities (barium content in the sedi- ment). The multivariate methods indicated changes in faunal composition at between 2 and $3 \mathrm{~km}$ radius from the Ekofisk site and $1.5 \mathrm{~km}$ from Eldfisk.

The clear groupings determined by the multivariate analyses at both Ekofisk and Eldfisk suggest that the first effects of oil-related activities that were found on the benthic fauna were (1) increased abundance of some species (12 of the top 15 ranked in terms of their contribution to average dissimilarity between cluster groupings), and (2) changes in the presence and absence patterns of rare species.

In relation to changes in presence and absence patterns, one might expect that rare species would become rarer and locally extinct under the influence of disturbance. In fact, at Ekofisk, whereas 10 species present in 

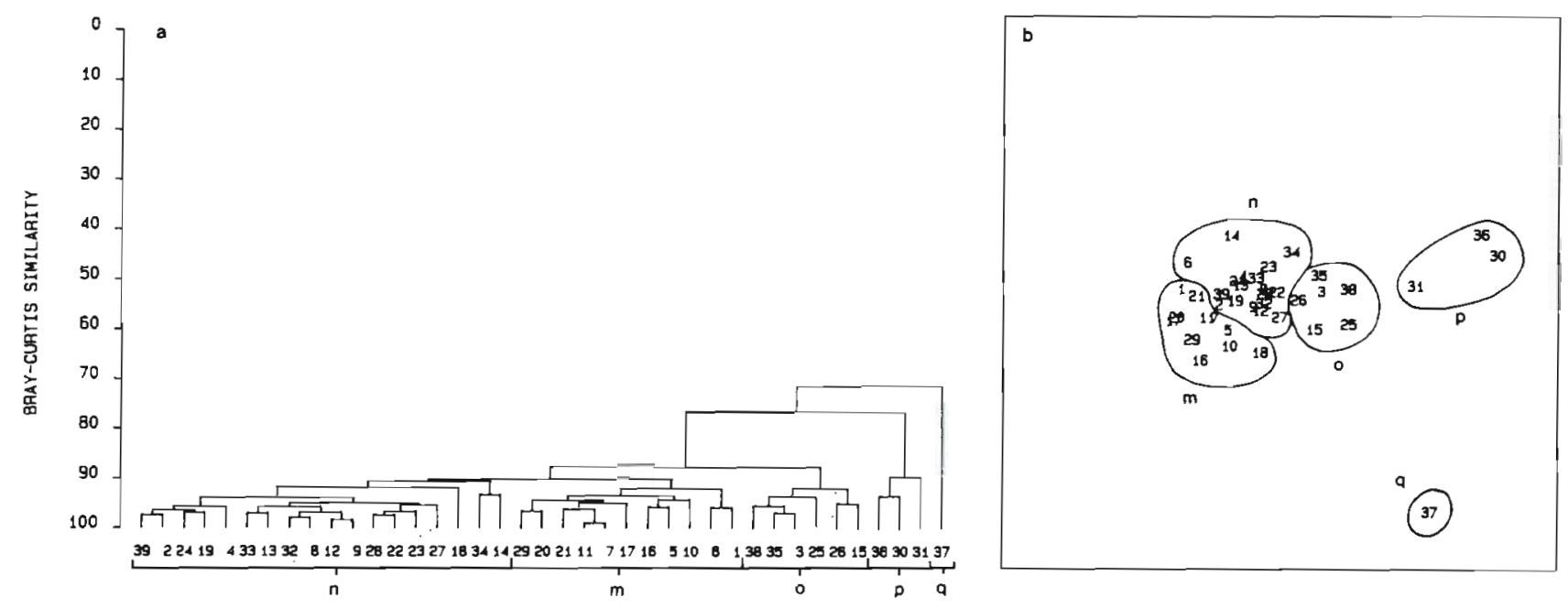

Fig. 14. Ekofisk quantitative data ( $V$ transformed) for 4 major phyla only. (a) Classification analysis; (b) MDS ordination (stress $=$ 0.10 ). Numbers refer to sites (Fig. 1a); letters to site groups separated at $88 \%$ dissimilarity

the unpolluted A group of sites were absent in the $\mathrm{B}$ group of sites, many more species (46) were present in the $\mathrm{B}$ group and absent in the A group and none of the 56 species were individually important in producing the $\mathrm{A}: \mathrm{B}$ division. The species that were highlighted by the SIMPER analysis as contributing to the A : B distinction were those which were mostly present in one group and mostly absent in another. These species do not become totally absent at all sites within the group but the frequency of their presence changes.

A possible scenario is that disturbance gives an advantage to some species which increase abundance, and leads to eradication of some rare species, whereby different species are able to colonise in low numbers. The disturbance leads to an increase in the mean number of species per site group at Ekofisk, from 50.2 (CI \pm 3.72 ) in the unpolluted group to 55.45 ( $\mathrm{CI} \pm 2.65$ ) at the initially disturbed group, to $57.5(\mathrm{CI} \pm 4.84)$ at the moderately disturbed group. Whilst this is in accordance with the intermediate disturbance hypothesis (Connell 1975), an analysis of variance shows that there is no significant difference $(p=0.05)$ between these 3 site groups.

As disturbance increases at the most polluted site, opportunist species have increased further in abundance and more species are eliminated giving a decrease in mean number of species to 45.0 (CI \pm 6.85 ) at Ekofisk. Yet the changes are not simply loss of species. Eleven of the species present at $A$ are absent at $B, 34$ are absent at $C$ and 70 are absent at $D$. At $B$ there are 46 species present which are not present at $A$ and at $C$ there are 25 , and even $D$ has 14 species which were not present at $\mathrm{A}$. So there are 2 trends in the presence and absence data; loss of many species in part compensated by gain of some new ones.

An inspection of the data shows that there are no obvious patterns, for example, in feeding-types or lifehistory characteristics of those species that become locally extinct or those that colonise. An appropriate model is perhaps that most of these species are rare (Ugland \& Gray 1982) and that mortality, induced by drill-cutting discharges, leads to local extinctions. Thus, there are vacant niches which are initially colonised in a random fashion leading to an increase in species number. In an environment without further disturbance both random and competitively induced mortality lead to a reduction in number of species back to the equilibrium level. At Ekofisk and Eldfisk the rate of disturbance increases (sites in groups C and IV) and mortality rates increase leading to a decrease in total species number, but still some species are able to colonise. At the most extreme case of disturbance (group D sites at Ekofisk), mortality rates have increased further and few species are able to colonise the available niche spaces. However, some species thrive in such conditions, namely opportunist species like Capitella capitata and Chaetozone setosa. These species are common in organically enriched areas (Pearson \& Rosenberg 1978).

One of the most surprising aspects is that after aggregation to higher taxa, even to the level of phyla, the multivariate analyses are still able to distinguish the major site groups. This supports findings of Warwick (1988) and Heip et al. (1988). As these authors make clear, such results should be of major importance to those involved in routine marine monitoring work. If this finding turns out to be a general one then instead of the extremely time-consuming species determinations it appears that more rapid phyla determinations may be made without much loss in precision, provided that multivariate analyses of the type done here are used. The reasons for this are unclear. In the sea phyle- 
tic diversity is extremely high and the above results suggest that both species and phyla show sequential responses to stressors. One of the cornerstones of ecology is the belief that species and the unique niche of a species are important. It may well be that the finer responses possible with analyses at the level of species are not needed to establish broad effects, such as those studied here. Clearly more research needs to be done in this area.

Meanwhile, at least in the context of monitoring around North Sea oil platforms, we would recommend that identification should still be done to species until such time that the generality of the ability of determinations to phyla alone to distinguish adequately between sites has been confirmed. What this study has established is that the use of multivariate analyses does, however, appear capable of providing diagnostic monitoring of change caused by oil activities.

Acknowledgements. The authors thank Phillips Petroleum for permission to use these data and to the Oil Pollution Research Unit for agreeing to collaborate on this paper. The Norwegian State Pollution Board (SFT) are acknowledged for insisting on good quality monitoring, which provided the basis for this study. Thanks are also due to 3 anonymous referees who gave extremely valuable criticism of the manuscript which thereby has been improved.

\section{LITERATURE CITED}

Boesch, D. F. (1971). Distribution and structure of benthic communities in a gradient estuary. Ph.D. thesis, Virginia Institute of Marine Science, Gloucester Point, Virginia

Connell, J. H. (1975). Some mechanisms producing structure in natural communities: a model and evidence from field experiments. In: Cody, M. L., Diamond, J. M. (eds.) Ecology and evolution of communities. Harvard University Press, Cambridge, p. 460-490

Dauvin, J.-C., Gentil, F. (1990). Conditions of the peracarid populations of subtidal communities in northern Brittany ten years after the Amoco Cadiz oil spill. Mar. Pollut. Bull. 21: $123-130$

Davies, J. M., Addy, J. M., Blackman, R., Blanchard, J. R., Moore, D. C., Somerville, H. J., Whitehead, A., Wilkinson, $\mathrm{T}$ (1984). Environmental effects of oil based mud cuttings. Mar. Pollut. Bull. 15: 363--370

Field, J. G. (1970). The use of numerical methods to determine benthic distribution patterns from dredgings in False Bay. Trans. R. Soc. S. Afr. 39: 183-200

Field, J. G., Clarke, K. R., Warwick, R. M. (1982). A practical strategy for analysing multispecies distribution patterns. Mar. Ecol. Prog. Ser. 8: 37-52

Gray, J. S. (1989). Effects of environmental stress on species rich assemblages. Biol. J. Linn. Soc. 37: 19-32

Gray, J. S., Aschan, M., Carr, M. R., Clarke, K. R., Green, R. H., Pearson, T. H., Rosenberg, R., Warwick, R. M. (1988). Analysis of community attributes of the benthic macrofauna of Frierfjord/Langesundfjord and in a mesocosm experiment. Mar. Ecol. Prog. Ser. 46: 151-165
Gray, J. S., Pearson, T H. (1982). Objective selection of sensitive species indicative of pollution-induced change in benthic communities. I. Comparative methodology. Mar. Ecol. Prog. Ser. 9: 111-119

Hartley, J. P. (1984). The benthic ecology of the Forties Oilfield (North Sea). J. exp. mar Biol. Ecol. 80: 161-195

Heip, C., Warwick, R. M., Carr, M. R., Herman, P. M. J., Huys, R., Smol, N., Van Holsbeke, K. (1988). Analaysis of community attributes of the benthic meiofauna of Frierfjord/ Langesundfjord. Mar Ecol. Prog. Ser. 46: 171-180

Hobbs, G. (1987). Environmental survey of the benthic sediments of the Ekofisk and Eldfisk oilfields, July 1987. Oil Pollution Research Unit Report No. FSC/OPRU/24/87, Oil Pollution Research Unit, Field Studies Council, Orielton Field Centre, Pembroke, Dyfed SA71 5EZ, UK

Hughes, R. N., Thomas, M. L. H. (1971a). The classification and ordination of shallow-water benthic samples from Prince Edward Island, Canada. J. exp. mar. Biol. Ecol. 7 : $1-39$

Hughes, R. N., Thomas, M. L. H. (1971b). Classification and ordination of benthic samples from Bedque Bay, an estuary on Prince Edward Island, Canada. Mar. Biol. 10: 227-235

Kingston, P. F. (1987). Field effects of platform discharges on benthic macrofauna. Phil. Trans. R. Soc. Lond. B 316 : 545-565

Pearson, T. H., Gray, J. S., Johannessen, P. J. (1983). Objective selection of sensitive species indicative of pollutioninduced change in benthic communities. 2. Data analyses. Mar. Ecol. Prog. Ser. 12: 237-255

Pearson, T H., Rosenberg, R. (1978). Macrobenthos succession in relation to organic enrichment and pollution of the marine environment. Oceanogr. mar. biol. A. Rev. 16: 229-311

Rapport, D. J., Regier, H. A., Hutchinson, T. C. (1985). Ecosystem behaviour under stress. Am. Nat. 125: 617-640

Reiersen, L.-O., Gray, J. S., Palmork, K., Lange, R. (1989). Monitoring in the vicinity of oil and gas platforms; results from the Norwegian sector of the North Sea and recommended methods for forthcoming surveillance. In: Engelhardt, F. R., Ray, J. P., Gillam, A. H. (eds.) Drilling wastes. Elsevier Applied Science, London, p. 91-117

Schindler, D. W. (1987). Detecting ecosystem responses to anthropogenic stress. Can. J. Fish. aquat. Sci. 44: 6-25

Stephenson, W., Williams, W. T., Lance, G. N. (1970). The macrobenthos of Moreton Bay. Ecol. Monogr. 42: $387-415$

Ugland, K. I., Gray, J. S. (1982). Lognormal distributions and the concept of community equilibrium. Oikos 39: $171-178$

Warwick, R. M. (1986). A new method for detecting pollution effects on marine macrobenthic communities. Mar. Biol. 92: $557-562$

Warwick, R. M. (1988). Analysis of community attributes of the benthic meiofauna of Frierfjord/Langesundfjord at taxonomic levels higher than the species. Mar. Ecol. Prog. Ser. 46: 167-170

Warwick, R. M., Carr, M. R., Clarke, K. R., Gee, J. M., Green, R. H. (1988). A mesocosm experiment on the effects of hydrocarbon and copper pollution on a sublittoral softsediment meiobenthic community. Mar. Ecol. Prog. Ser. 46: 181-191

Warwick, R. M., Clarke, K. R., Suharsono (1990). A statistical analysis of coral community responses to the 1982-3 El Nino in the Thousand Islands, Indonesia. Coral Reefs 8 : $171-179$

Manuscript first received: February 27, 1990

Revised version accepted: June 21, 1990 